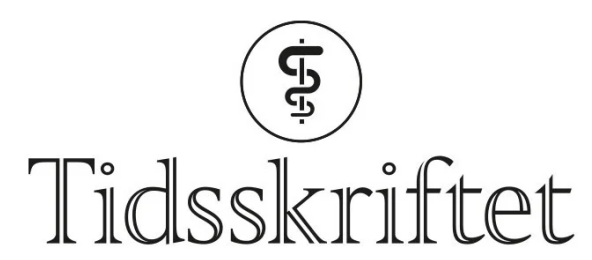

DEN NORSKE LEGEFORENING

\title{
En ny normal for universitetsundervisning
}

DEBATT

\section{CHRISTOFFER DRABLØS VELDE}

cdvelde@hotmail.com

Christoffer Drabløs Velde er medisinstudent ved Universitetet i Bergen og leder for Norsk medisinstudentforenings lokallag i Bergen.

Forfatteren har fylt ut ICMJE-skjemaet og oppgir ingen interessekonflikter.

\section{JONAS HODNELAND SUNDFJORD}

Jonas Hodneland Sundfjord er medisinstudent ved Universitetet i Bergen og grunnutdanningsansvarlig for Norsk medisinstudentforenings lokallag i Bergen. Forfatteren har fylt ut ICMJE-skjemaet og oppgir ingen interessekonflikter.

\section{Medisinstudentene savner ikke å sitte isolert på hybelen. Men kan vi fortsatt få gode digitale forelesningsvideoer som et supplement til den tradisjonelle undervisningen?}

25. september 2021 åpnet samfunnet endelig opp, etter til sammen 562 dager med landsdekkende restriksjoner. Universitetene ble tvunget til å tenke nytt da restriksjonene ble innført i mars 2020, nærmest over natten. Fysiske forelesninger ble til digitale videoer, og campuser ble stengt.

Omleggingen av undervisningsform har gitt utdanningsinstitusjonene erfaring fra en alternativ studiehverdag. Denne hverdagen kunne vi studenter tilpasse slik vi selv ville, slik at vi leste pensum i vårt tempo, og vi kunne se forelesninger til alle døgnets tider. Dette er positive erfaringer fra undervisningen under pandemien, som vi gjerne vil beholde nå som vi kommer tilbake på campus. Likevel har pandemien vist oss hvor viktig campus er som en sosial møteplass og arena for utvikling av vår profesjonelle identitet. Undervisning på campus gir oss en følelse av sosial tilhørighet og faglig mestring, som vi vet står sentralt i et godt studentliv (1). At noen spør hvor du er når du ikke møter til forelesning, kan gi en følelse av å bli sett.

Undervisningen bør være en kombinasjon av fysisk fremmøte og gode digitale forelesninger, tilgjengelig når det passer studenten. Mennesker lærer på ulike måter: noen visuelt, noen skriftlig og noen auditivt (르). Å tilby flere former for undervisning om samme tema kan bidra til bedre læring hos studentene. Videoene åpner for en dynamisk 
studiehverdag, hvor det er lettere å kombinere studier med jobb, sykdom eller andre forpliktelser. De er også nyttige for oppfriskning av temaer man er usikker på før eksamen. Undervisningen bør ikke bli som den var før pandemien.

\section{Det beste av begge verdener}

Selv om mye bra undervisningsmateriell er produsert, finnes det også videoer som ikke egner seg for gjenbruk. Vi har erfart at gode videoforelesninger kjennetegnes av kort varighet, konkret tema og enkle forklaringer. Når foreleser ikke har mulighet til å besvare spørsmål, er det viktig at videoene er forståelige for studentene. Foreleser har langt mer erfaring og kunnskap enn studenten, og da er det lett for kua å glemme at den en gang var kalv. I tillegg må vi være oppmerksomme på at videoene, i likhet med pensumbøkene, må oppdateres i takt med den medisinske utviklingen. Det som er fakta i dag, kan være feil om ti år.

Utfordringen fremover blir å finne den gylne middelvei i mengden digital og fysisk undervisning. Mens fysiske forelesninger åpner for faglig diskusjon med foreleser, er digitale forelesninger teorikompakte monologer basert på pensumlitteraturen. Fysiske forelesninger kan profittere på at monologen er gjennomgått på forhånd, da det blir mer tid til å skape en helhetlig forståelse av temaet. Her gjelder å finne en balanse, og det er ikke et fasitsvar på hvordan undervisningen bør se ut. Både digital og fysisk undervisning har en plass i utdanningen - de utfyller hverandre.

\section{LITTERATUR}

1. Meland KJ. Dette sier studentene om det gode studentlivet. Forskning.no 6.11.2019. https://forskning.no/partner-skole-og-utdanning-universitetet-i-sorost-norge/dette-sier-studenteneom-det-gode-studielivet/1587594 Lest 26.10.2021.

2. Dunlosky J, Rawson KA, Marsh EJ et al. Improving students' learning with effective learning techniques: Promising directions from cognitive and educational psychology. Psychol Sci Public Interest 2013; 14: 4-58. [PubMed][CrossRef]

Publisert: 10. januar 2022. Tidsskr Nor Legeforen. DOI: 10.4045/tidsskr.21.0761

Mottatt 28.10.2021, godkjent 16.11.2021.

(C) Tidsskrift for Den norske legeforening 2023. Lastet ned fra tidsskriftet.no 26. april 2023. 